\title{
Analysis Performance Cost and Implementation with Earned Value Method
}

\author{
[Herby Calvin Pascal Tiyow ${ }^{1}$ and Irwan Lie Keng Wong ${ }^{2}$ ]
}

\begin{abstract}
Earned Value Method is a method developed to determine the progress of the project based on the progress that has been achieved. This method will provide very useful information when applied to evaluate project progress in order to identify potential slippage and use of budget overruns. The concept of an earned value has three main components: the budget cost, the actual cost, and a value derived from the cost that has been issued or called the earned value. The research was carried out on the project of Faculty of Engineering Development of Hasanuddin University in Makassar, South Sulawesi. The research method is an intrusive analysis by analyzing project performance after the $13^{\text {th }}$ week. The results showed that the application of the earned value method showed that the project time performance from the first week to the 13th week experienced several deviations, ie at the $4^{\text {th }}, 8^{\text {th }}$ and $13^{\text {th }}$ weeks. So the project has decreased time performance at a cost that is less than the budget.
\end{abstract} Value

Keywords - Cost, Performance, Implementation, Earned

\section{Introduction}

Planning and Cost Control and Time are part of the overall construction project management. In addition to quality assessment, the achievement of a project can also be assessed in terms of cost and time. The costs incurred and the time spent in completing a job are often deviated and should be continuously measured against the plan. The presence of significant cost and time deviations indicates poor project management. Given this cost and time achievement indicator, it is possible to prevent the implementation of the project as planned.

\section{Project}

The project is a one-off activity with limited time and resources to achieve a predetermined end result. According by Imam Soeharto, 1996; The project has the following key features:1). produce a certain deliverable in the form of the final product or the final work; 2) determined cost, time schedule and quality criteria; 3 ) temporary, in the sense of age is limited by the completion of the task. The starting and ending points are clearly defined; 4) non routine, not repetitive. Kinds and identity activities change throughout the project.

Herby Calvin Pascal Tiyow

Universitas Kristen Indonesia Paulus Makassar

South Sulawesi, Indonesia.

Irwan Lie Keng Wong

Universitas Kristen Indonesia Paulus Makassar

South Sulawesi, Indonesia.

\section{Earned Value Method}

As the complexity of the project becomes more complicated, there are often delays in project completion and cost overrun. New concept that integrates the cost and time aspects, which is called earned value. This concept helps in overcoming the two problems above so that project cost expenditure can be controlled and able to reach the planned target time.

Fleming and Koppelman (1994) explain differences in the concept of earned value compared with traditional cost management. Traditional cost management only presents a simple relationship between the actual cost and the cost of the plan so that performance can not be known. Conversely, the concept of earned value can indicate the actual cost and cost of the plan as well as the physical conditions of the work completed.

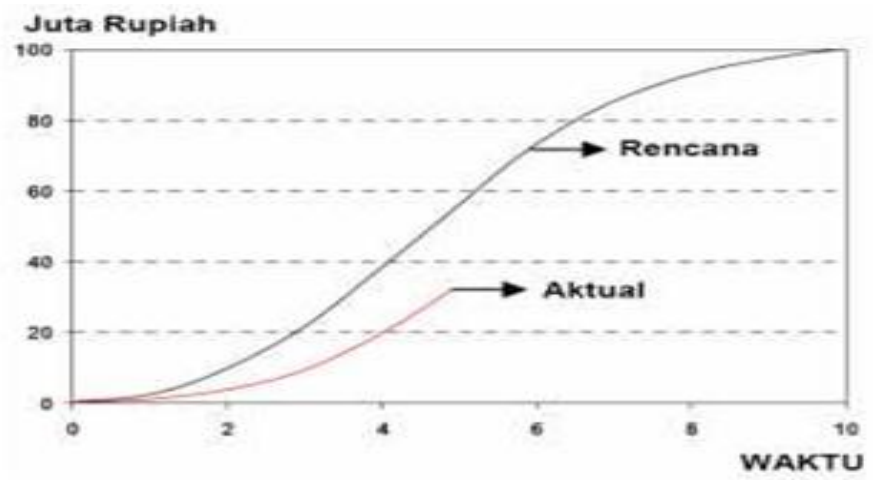

Figure 1. Traditional Cost Management

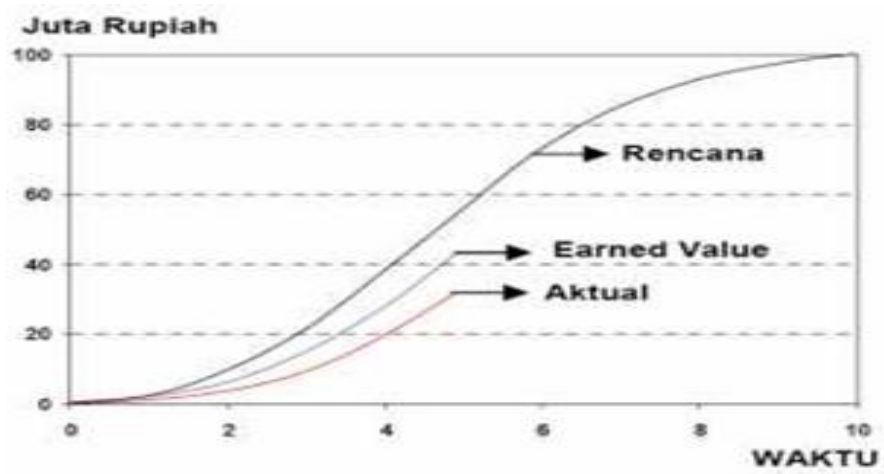

Figure 2. Earned value method

Source: Earned Value Concept Paper for Construction Project Management, Biemo W.Soemardi et al.

Figure 1, it can be seen that actual costs are lower, but the fact that the actual cost lower than this plan can not show that the performance that has been done is in accordance with the target plan and In Figure 2 the magnitude of the completed physical work or the earned value/percent complete is 
indicated so that the project manager will be able to better understand how much performance resulting from the amount of costs that have been incurred.

There are three basic components in analyzing the performance of a project based on the concept of earned value:1) Budget Cost of Work Schedule (BCWS); 2) Actual Cost of Work Performance (ACWP); 3) Budget Cost of Work Performance (BCWP).

\section{Budget Cost of Work Schedule (BCWS)}

BCWS is the cost budget allocated based on the work plan that has been prepared against time. BCWS is calculated from the accumulated cost budget planned for the job within a certain period of time. BCWS at the end of the project $(100 \%$ settlement) is called Budget at Completion (BAC). BCWS is also a benchmark of time performance of project implementation. BCWS reflects the cumulative cost-allocation of plans for each work package according to the order in which it is planned.

\section{Actual Cost of Work Performance (ACWP)}

ACWP is a representation of the total expenditure incurred to complete the work within a certain period. ACWP can be cumulative up to the period of performance calculation or the amount of expense expenses within a certain period of time.

\section{Budget Cost of Work Performance (BCWP)}

$\mathrm{BCWP}$ is the value received from the completion of work over a specified period of time. BCWP is called the value of the result or Earned Value (EV). BCWP is calculated on the basis of the accumulation of completed works. Calculation of the value of the result is with:

$$
\text { Earned Value }(\mathrm{EV})=\% \text { completion } \mathrm{x} \text { Budget }
$$

$\%$ Completion achieved at the time of reporting (progress)

The budget is the project cost budget (RAB).

\section{Iv. Concept EVM on Perfomance Project}

The use of the earned value concept in project performance appraisal is explained through Figure 3.

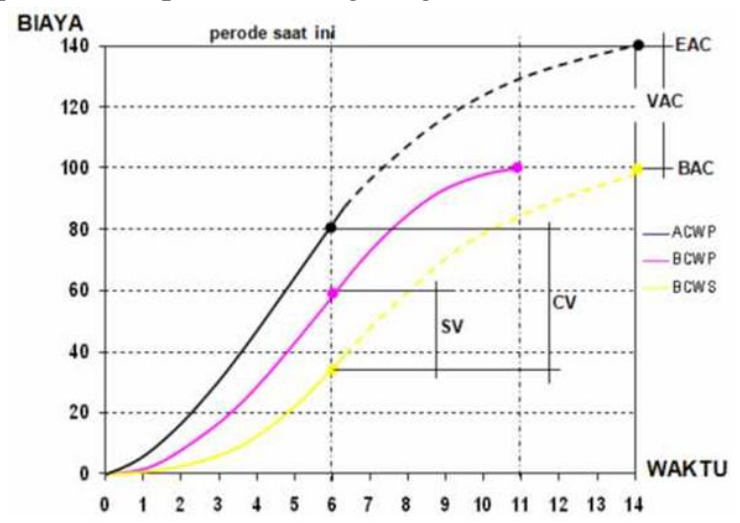

Figure 3. Curve S Earned Value

The important definitions associated with this assessment are Cost Variance, Schedule Variance, Cost Performance Index, Schedule Performance Index, Estimate at Completion, and Variance at Completion

1. Cost Variance (CV)

Cost variance is the difference between the value obtained after completing the work packages at the actual cost during the project implementation. The positive cost variance shows that the value of work packets obtained is greater than the cost incurred to work on the work packages. In contrast, the negative value indicates that the value of the completed work packages is lower than the cost incurred.

$$
\mathrm{CV}=\mathrm{BCWP}-\mathrm{ACWP}
$$

\section{Schedule Variance (SV)}

Schedule variance is used to calculate the deviation between BCWP and BCWS. A positive score indicates that the project work packages that are executed outweigh the plans. Conversely, negative values show poor job performance because the work packets that are executed are fewer than the planned schedule.

$$
\mathrm{SV}=\mathrm{BCWP}-\mathrm{BCWS}
$$

Table 1. Integrated Variance Analysis

\begin{tabular}{|c|c|l|}
\hline SV & CV & \\
\hline positive & positive & $\begin{array}{l}\text { Work done faster than on a schedule at } \\
\text { a cost less than the budget }\end{array}$ \\
\hline zero & positive & $\begin{array}{l}\text { Work is done on schedule at a cost } \\
\text { lower than the budget }\end{array}$ \\
\hline zero & zero & Work is done on schedule and budget \\
\hline negative & negative & $\begin{array}{l}\text { The work is overdue and costs more } \\
\text { than the budget }\end{array}$ \\
\hline zero & negative & $\begin{array}{l}\text { Work is done on schedule with a cost } \\
\text { over the budget }\end{array}$ \\
\hline negative & zero & $\begin{array}{l}\text { The work is overdue and the cost is } \\
\text { within budget }\end{array}$ \\
\hline positive & negative & $\begin{array}{l}\text { The work finished faster than plan with } \\
\text { cost above budget }\end{array}$ \\
\hline
\end{tabular}

\section{Cost Performance Index (CPI)}

The cost efficiency factors that have been incurred in project implementation can be shown by comparing the value of physically completed work (BCWP) with the costs incurred in the same period (ACWP).

If,

$$
\text { CPI UCW: }
$$

$\mathrm{CPI}=0$; the actual cost in accordance with the cost of the plan $\mathrm{CPI}<1$; the actual cost is greater than the cost of the plan CPI $>1$; the actual cost is less than the cost of the plan

\section{Schedule Performance Index (SPI)}

The performance efficiency factor in completing the work can be demonstrated by the comparison between the value of the physically completed work (BCWP) and the planned expenditure plan based on the work plan (BCWS). SPI stw:"

Where : 
Proc. of Eighth International Conference On Advances in Civil, Structural and Mechanical Engineering - ACSM 2018 Copyright (C) Institute of Research Engineers and Doctors, USA. All rights reserved.

ISBN: 978-1-63248-154-2 doi: 10.15224/978-1-63248-154-2-26

\section{BCWP = Budget Cost of Work Performance \\ BCWS = Budget Cost of Work Schedule}

CPI and SPI indicators are more commonly used for project performance appraisal than SV and CV. CPI and SPI values are the weights of values that do not have dimensions that can be done comparison between project performance with each other. In addition, the SPI and CPI scores provide a comparison relative to BCWS or the Performance Measurement Baseline (PMB) which is the basis for assessing project status in terms of cost and time.

\section{Budget Estimate To Complete (B-ETC)}

B-ETC is a cost estimate for residual work with the assumption that the trend of project performance will remain up to the end of the project

$$
B \text { ETC עA-uCw: }
$$

\section{Budget Estimate at Completion (B- EAC)}

The importance of calculating CPI and SPI is to predict statistically the costs required to complete the project. There are many methods in predicting the cost of completion of the project (B-EAC). However, the calculation of B-EAC with SPI and CPI is easier and faster to use.

$$
\text { B EAC) } A C W P \text { । } D \text { ETC }
$$

The B-EAC calculation is the actual cost sum that has been incurred with the remaining costs that will be required to complete the project. The remaining costs to be required are predicted statistically by taking into account the effectiveness of the use of cost (CPI) and performance of the work against the plan (SPI). It can then be estimated that the difference between the cost of the project completion plan is called the Budget at Completion (BAC) with the cost of completion of the project based on the performance achieved (EAC) or called Variance at Completion (VAC)

$$
\text { VAC BAC D_EAC }
$$

\section{Schedule Estimate To Cmplete (S-ETC)}

$\mathrm{S}$-ETC is an approximate time for residual work with the assumption that the trend of project performance will remain up to the end of the project

$$
S \quad E T C \text { y-at. -ystw }
$$

8. Scheduled Estimate At Complete (S-EAC)

The assumption used to estimate the completion time is that project performance will remain as it was during the review

$$
\mathrm{S}-\mathrm{EAC}=\mathrm{ETD}+\mathrm{S}-\mathrm{ETC}
$$

\section{v. Case Study Project}

Case study on Hasanuddin University Faculty of Engineering Development Project, addres Poros Malino Km.12 Gowa Regency. Makassar South Sulawesi Province, Indonesia The research at Hasanuddin University Faculty of Engineering Development Project starts from $3^{\text {th }}$ week to $13^{\text {th }}$ week.

Research methodology is an intrusive analysis where primary data and secondary data obtained then processed by earned value method analysis then taken a decision in the form of conclusion

\section{vI. Flow diagram}

Flow diagram is shown in the following Figure 2:

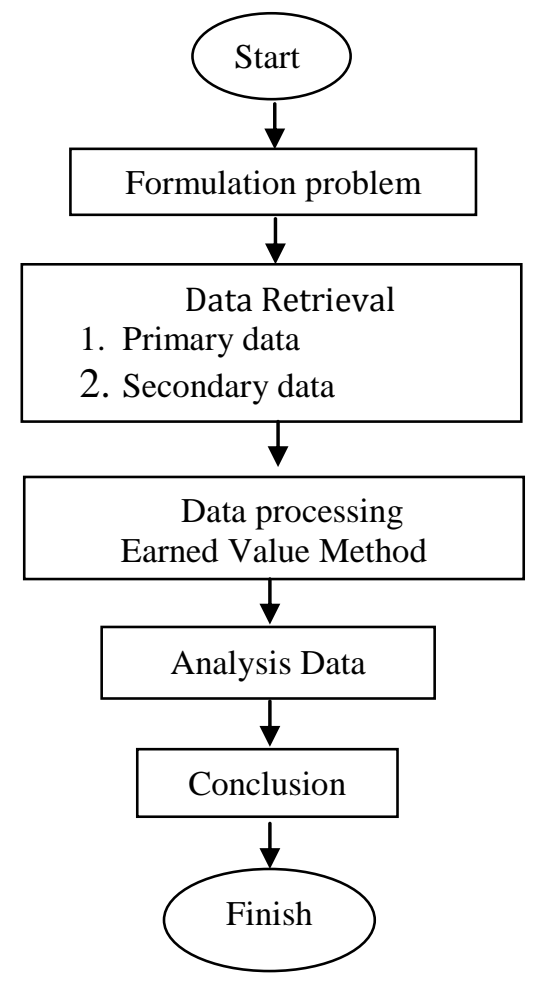

Figure 2. Flow diagram

\section{vII. Analysis Data}

Evaluation is done by analyzing the results of project performance every week, so that can be seen project performance and deviation

Evaluation Project of the 3rd week

Bugdet $(\mathrm{BAC}) \quad=$ Rp.129,035,484,764,637.00

Time plan (OD) $\quad=65$ minggu

Time Completion $=0.393 \%$

Actual realize $(\%) \quad=0.445 \%$

Basic parameter Earned Value

BCWS = Bugdet $\mathrm{x}(\%)$ time completion $=$ Rp. $129,035,484,764.637 \times 0.393 \%$ $=$ Rp.507,109,455.13

BCWP = Bugdet $\mathrm{x}(\%)$ actual realize $=$ Rp. $129,035,484,764.637 \times 0.445 \%$ $=$ Rp.574,207,907.20

ACWP = Rp.574,587,664.94

Variant / Deviation of Project Performance

$\mathrm{SV}=\mathrm{BCWP}-\mathrm{BCWS}$

$=$ Rp.574,207,907.20 - Rp.507,109,455.13

= Rp.67,098,452 (positive; quick project)

$\mathrm{CV}=\mathrm{BCWP}-\mathrm{ACWP}$ 
Proc. of Eighth International Conference On Advances in Civil, Structural and Mechanical Engineering - ACSM 2018 Copyright ( Institute of Research Engineers and Doctors, USA. All rights reserved.

ISBN: 978-1-63248-154-2 doi: 10.15224/978-1-63248-154-2-26

$=$ Rp.574,207,907.20 - Rp.574,587,664.94

$=-$ Rp. $379,757.74$

(negative; the actual cost is less than the cost of the plan)

Index of Project Performance Efficiency

SPI $=1.132$ (index $>1$; the project is accelerating

$\mathrm{CPI}=0.999$ (index $<1$; actual cost $>$ plan cost)

Table 2. Evaluate project performance from the first week to the $13^{\text {th }}$ week

\begin{tabular}{|c|c|c|c|c|}
\hline \multirow{2}{*}{ Week } & \multirow{2}{*}{ Bugdet } & \multicolumn{2}{|c|}{ cumulative weight } & \multirow{2}{*}{$\begin{array}{c}\mathrm{EV} \\
\mathrm{BCWS}=\mathrm{b} \times \mathrm{c}\end{array}$} \\
\hline & & Plan & Realization & \\
\hline $\mathrm{a}$ & $\mathrm{b}$ & $\mathrm{c}$ & $\mathrm{d}$ & $\mathrm{e}$ \\
\hline 1 & \multirow{13}{*}{ 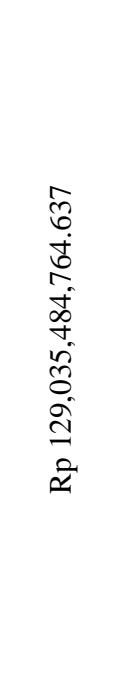 } & - & - & $\mathrm{Rp}$ \\
\hline 2 & & - & - & $\mathrm{Rp}$ \\
\hline 3 & & $0.393 \%$ & $0.445 \%$ & $\mathrm{Rp} \quad 507,109,455.13$ \\
\hline 4 & & $0.770 \%$ & $0.717 \%$ & $\mathrm{Rp} \quad 993,573,232.69$ \\
\hline 5 & & $0.904 \%$ & $0.934 \%$ & $\mathrm{Rp} \quad 1,166,480,782.27$ \\
\hline 6 & & $1.033 \%$ & $1.115 \%$ & Rp $1,332,936,557.62$ \\
\hline 7 & & $1.210 \%$ & $1.270 \%$ & Rp $1,561,329,365.65$ \\
\hline 8 & & $1.685 \%$ & $1.380 \%$ & Rp $2,174,247,918.28$ \\
\hline 9 & & $2.160 \%$ & $1.701 \%$ & $\operatorname{Rp} \quad 2,787,166,470.92$ \\
\hline 10 & & $2.571 \%$ & $2.541 \%$ & $\operatorname{Rp} 3,317,502,313.30$ \\
\hline 11 & & $3.617 \%$ & $4.163 \%$ & Rp $4,667,213,483.94$ \\
\hline 12 & & $4.656 \%$ & $5.278 \%$ & Rp $\quad 6,007,892,170.64$ \\
\hline 13 & & $5.735 \%$ & $5.319 \%$ & $\operatorname{Rp} 7,400,185,051.25$ \\
\hline
\end{tabular}

Continue Table 2. Evaluate project performance from the first week to the $13^{\text {th }}$ week

\begin{tabular}{|c|c|c|}
\hline \multirow{2}{*}{ Week } & EV & EV \\
\hline & $B C W P=b \times d$ & ACWP \\
\hline $\mathrm{a}$ & $\mathrm{f}$ & $\mathrm{g}$ \\
\hline 1 & $\mathrm{Rp}$ & $\mathrm{Rp}$ \\
\hline 2 & $\mathrm{Rp}$ & $\mathrm{Rp}$ \\
\hline 3 & Rp $\quad 574,207,907.20$ & Rp $\quad 574,587,664.94$ \\
\hline 4 & Rp $925,184,425.76$ & Rp $925,762,737.49$ \\
\hline 5 & $\mathrm{Rp} \quad 1,205,191,427.70$ & Rp 1,205,025,585.42 \\
\hline 6 & $\operatorname{Rp} \quad 1,438,745,655.13$ & Rp 1,438,538,159.11 \\
\hline 7 & Rp $1,638,750,656.51$ & Rp $1,643,141,210.06$ \\
\hline 8 & Rp $\quad 1,780,689,689.75$ & Rp $1,835,453,775.54$ \\
\hline 9 & Rp $\quad 2,194,893,595.85$ & Rp 2,327,165,816.90 \\
\hline 10 & Rp $3,278,791,667.87$ & Rp 3,262,778,756.77 \\
\hline 11 & Rp $\quad 5,371,747,230.75$ & Rp 5,348,546,423.87 \\
\hline 12 & Rp $\quad 6,810,492,885.88$ & Rp $6,777,001,960.63$ \\
\hline 13 & Rp $\quad 6,863,397,434.63$ & $\operatorname{Rp} 6,818,350,759.61$ \\
\hline
\end{tabular}

Continue Table 2. Evaluate project performance from the first week to the $13^{\text {th }}$ week

\begin{tabular}{|c|c|c|c|c|}
\hline \multirow{2}{*}{ Week } & \multicolumn{2}{|c|}{ Variant Performance } & \multicolumn{2}{|c|}{ Performance } \\
\hline & $\mathrm{CV}=\mathrm{f}-\mathrm{g}$ & $\mathrm{SV}=\mathrm{f}-\mathrm{e}$ & $\mathrm{CPI}=$ & SPI \\
\hline $\mathrm{a}$ & $\mathrm{h}$ & $\mathrm{i}$ & $\mathrm{j}$ & $\mathrm{k}$ \\
\hline 1 & $\mathrm{Rp}$ & $\mathrm{Rp}$ & - & - \\
\hline 2 & $\mathrm{Rp}$ & $\mathrm{Rp}$ & - & - \\
\hline 3 & $379,757.74$ & Rp $\quad 67,098,452.08$ & 0.999 & 1.132 \\
\hline 4 & $578,311.73$ & -Rp $\quad 68,388,806.93$ & 0.999 & 0.931 \\
\hline 5 & $165,842.28$ & Rp $38,710,645.43$ & 1.000 & 1.033 \\
\hline 6 & $207,496.02$ & Rp 105,809,097.51 & 1.000 & 1.079 \\
\hline 7 & -Rp $\quad 4,390,553.55$ & Rp 77,421,290.86 & 0.997 & 1.050 \\
\hline 8 & -Rp $\quad 54,764,085.79$ & -Rp 393,558,228.53 & 0.970 & 0.819 \\
\hline 9 & -Rp 132,272,221.05 & -Rp 592,272,875.07 & 0.943 & 0.788 \\
\hline 10 & $\operatorname{Rp} \quad 16,012,911.10$ & -Rp $38,710,645.43$ & 1.005 & 0.988 \\
\hline 11 & Rp $23,200,806.88$ & Rp 704,533,746.81 & 1.004 & 1.151 \\
\hline 12 & Rp $33,490,925.25$ & Rp 802,600,715.24 & 1.005 & 1.134 \\
\hline 13 & $\mathrm{Rp} \quad 45,046,675.02$ & -Rp 536,787,616.62 & 1.007 & 0.927 \\
\hline
\end{tabular}

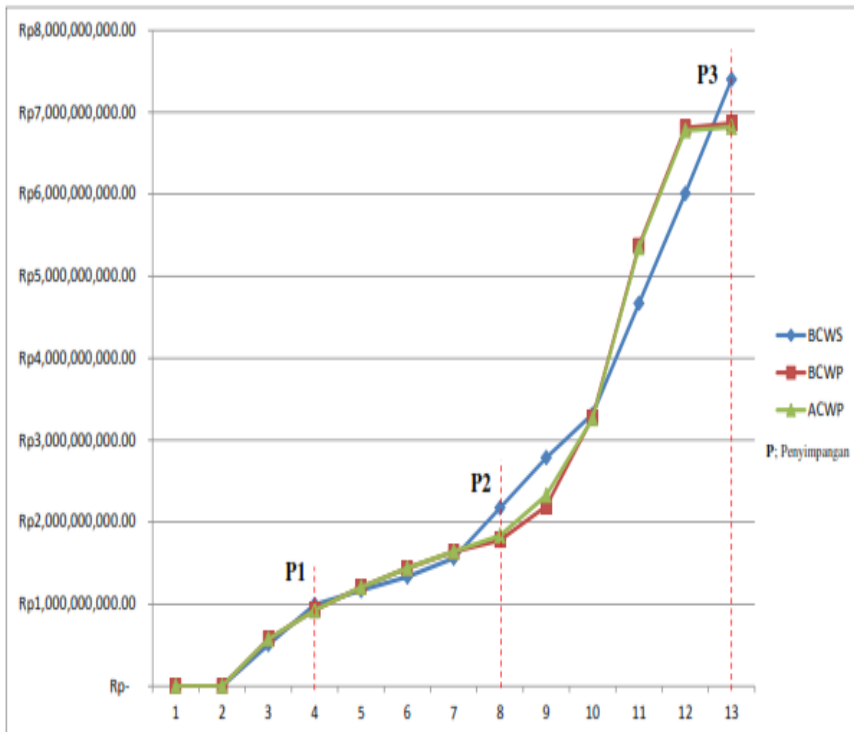

Figure 3. Graph of project performance evaluation from the first week to the $13^{\text {th }}$ week

Discussion

The results of the analysis show that the performance of the project time has been deviated in several weeks of implementation of the work, namely:

a. The $4^{\text {th }}$ week

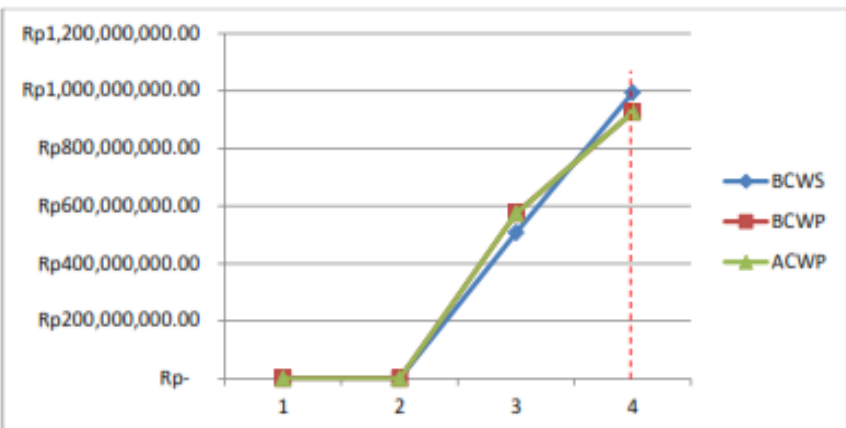

Figure 4. Graph interaction of BCWS, BCWP and ACWP 
Proc. of Eighth International Conference On Advances in Civil, Structural and Mechanical Engineering - ACSM 2018 Copyright ( $\odot$ Institute of Research Engineers and Doctors, USA. All rights reserved.

ISBN: 978-1-63248-154-2 doi: 10.15224/978-1-63248-154-2-26

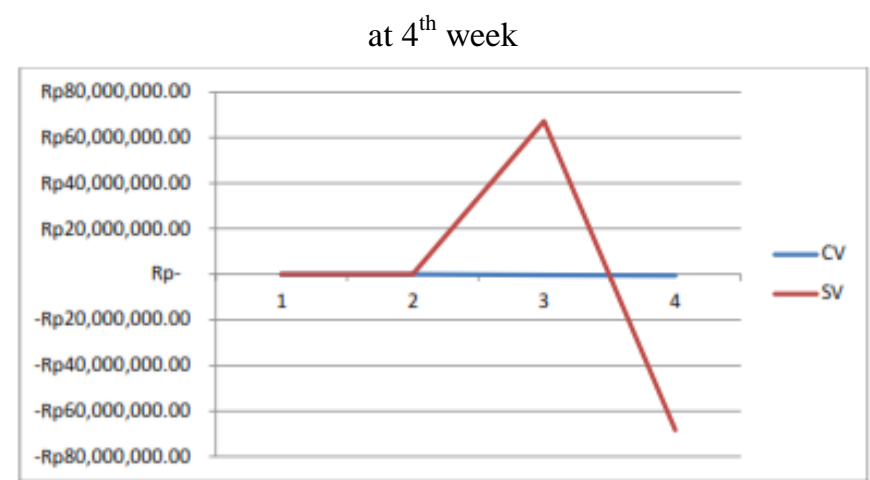

Figure 5. Graph of CV and SV interaction at $4^{\text {th }}$ week.

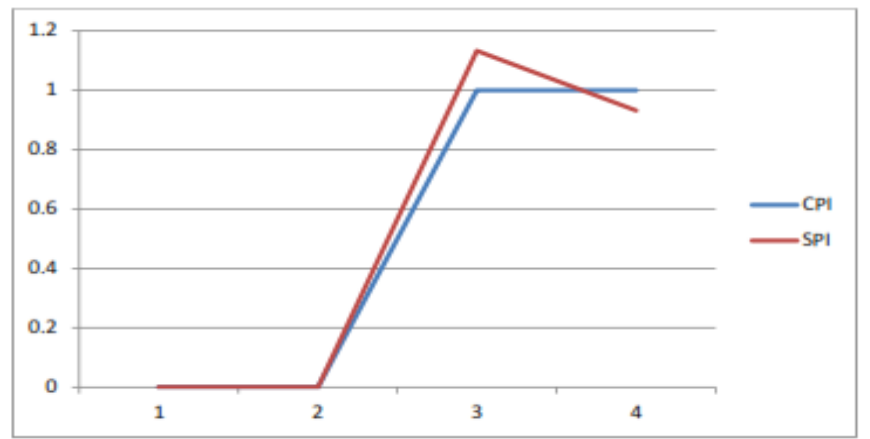

Figure 6. Graph of CPI and SPI interaction at $4^{\text {th }}$ week At $4^{\text {th }}$ week, the negative variant SV (-) and CV (-) variant values, this means the work is slower than the planned schedule and uses a higher cost than the budgeted. Seen from the performance index, the SPI indices $<1$ and the CPI index $<1$ so that it can be interpreted that the performance of the project is slower than the planned schedule and uses a higher cost than the budgeted

b. The $8^{\text {th }}$ week

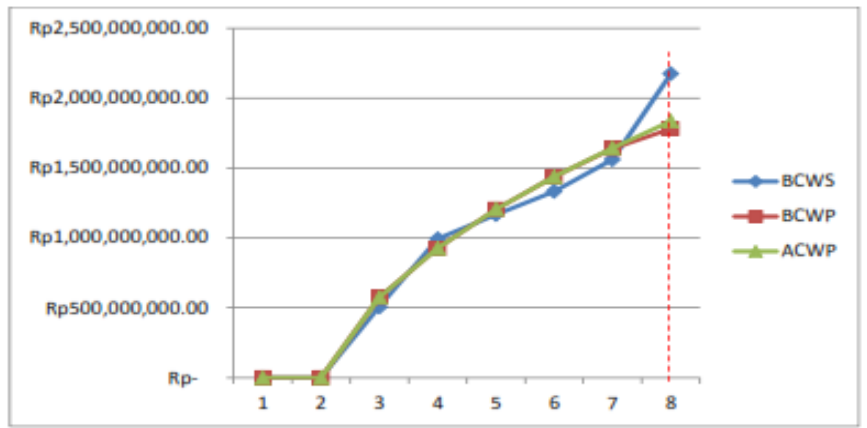

Figure 7. Interaction of BCWS, BCWP, and ACWP $8^{\text {th }}$ week

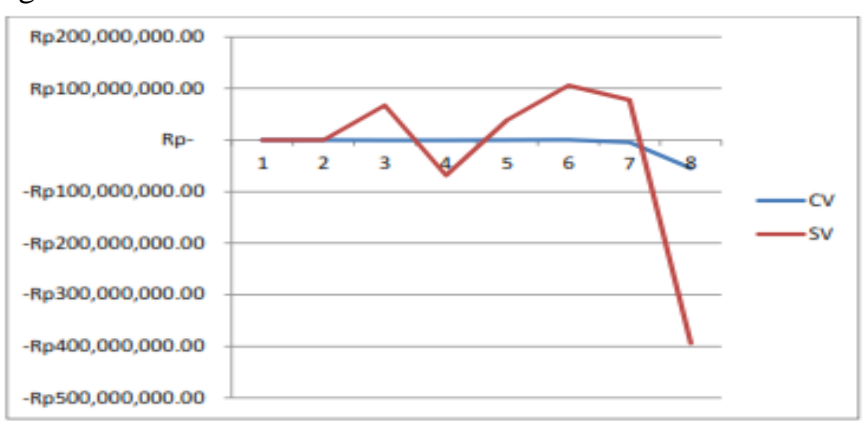

Figure 8. Graph of CV and SV interaction at $8^{\text {th }}$ week

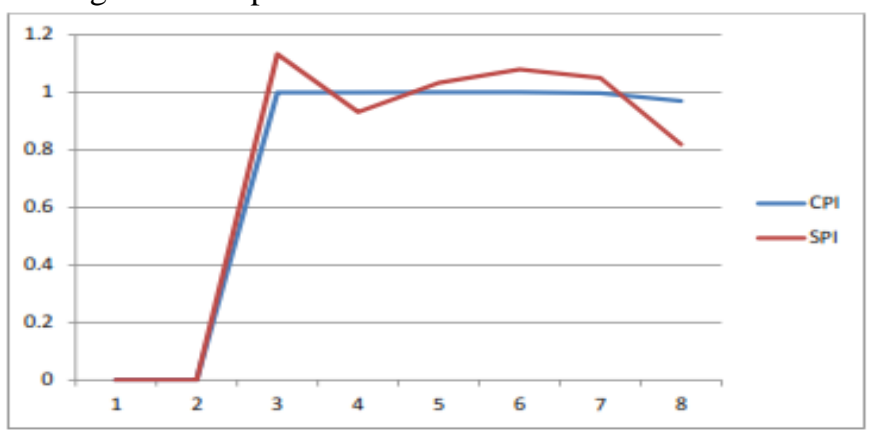

Figure 9. Graph of CPI and SPI interaction at $8^{\text {th }}$ week At $8^{\text {th }}$ week, the negative SV (-) variant values and CV (-) variant values are negative, meaning the work is slower than the planned schedule and uses a smaller cost than budgeted. Seen from the performance index, the SPI indices $<1$ and the $\mathrm{CPI}$ index $<1$ so that it can be interpreted that the performance of the project is slower than the planned schedule and uses a smaller cost than the budgeted

c The $13^{\text {th }}$ week

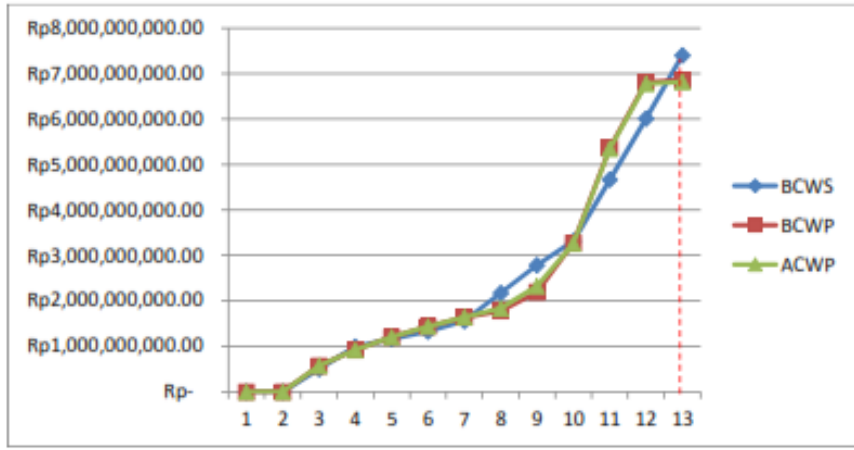

Figure 10. Interaction BCWS, BCWP, and ACWP $13^{\text {th }}$ week

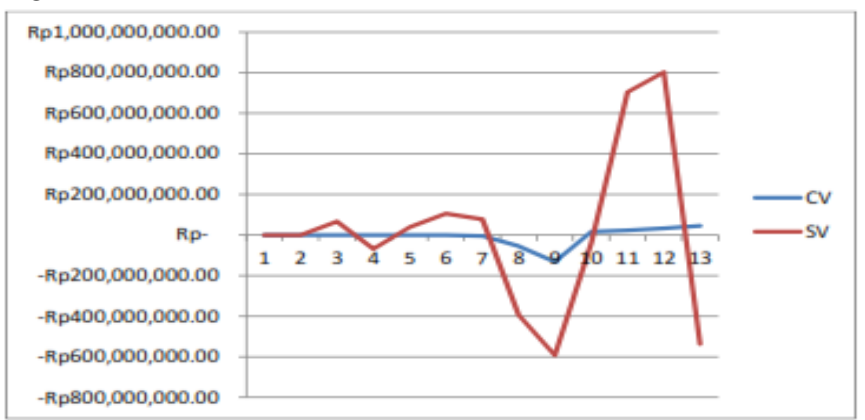

Figure 11. Graph of CV and SV interaction at $13^{\text {th }}$ week

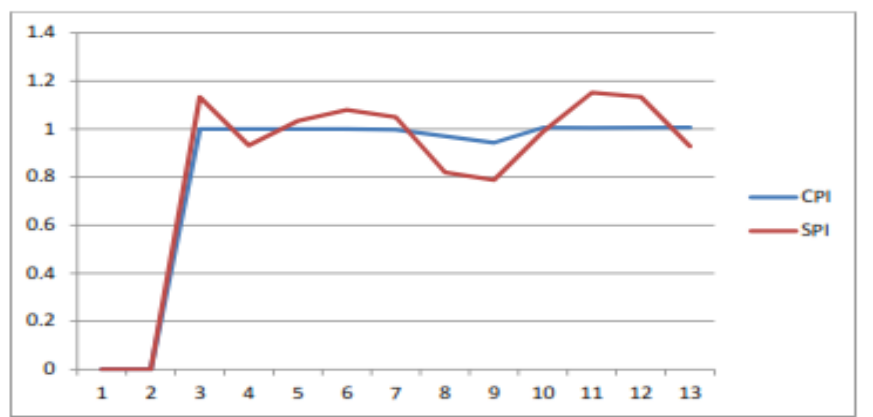


Figure 12. Graph of CPI and SPI interaction at $13^{\text {th }}$ week At $13^{\text {th }}$ week, the negative SV (-) variant and CV (-) negative value, meaning the job is slower than planned schedule and uses a larger cost than budgeted.

Viewed from the performance index, the SPI indices $<1$ and the CPI index value> 1 so that it can be interpreted that the performance of the project is slower than the planned schedule and uses a higher cost than the budgeted

\section{Causes Occurrence of Project Schedule Diversity}

In each implementation of the work on each project has different problems in accordance with the conditions and places where the project is implemented. The problem can be reviewed from both technical and non technical as follows: 1 . Technical Issues

\section{a. Measurement}

Before carrying out work such as foundation work, column and so on always start with measurement. However, in practice it often deviates several centimeters.

This is usually caused by the attention / worker control of the measurement that is less thorough. To anticipate this there is usually a tolerance that has been established on the contract work in accordance with the agreement. And if the size exceeds the tolerance limit then asked the decision of the consultant to provide solutions or work dismantled and reworked so that the impact on the time and cost of project implementation

b. Material / Equipment Delays

One of the causes of delay in the implementation of work on construction projects is the delay of materials / tools needed if not in the project location area implemented. This is usually caused by several things including; materials / tools not located in the vicinity of the project area so delivery must be done and in the delivery there is usually a weather constraint or other travel disruption.

c.Human error

Although all systems and equipment for work safety are adequate but sometimes worker negligence factors are common. This is usually because workers are less concerned about health and rest conditions that affect the implementation of the work.

d. Communication

The usual thing if ignored can have a tremendous impact, one of which is communication. This is strongly influenced by the boss who coordinates subordinates with different characters and diverse ethnic backgrounds. For that good communication management is necessary to be implemented during the project runs.

\section{Non technical issues}

a. Shop drawing

Delays in document shop drawing by the service provider after being checked by the surveillance service provider make the implementation schedule can be delayed until the shop drawing is approved (Approved).

b. Bad weather

One of the obstacles that is difficult to control is bad weather.
Bad weather especially rain is very influential on the implementation of work in the field, especially on the implementation of the work under the structure so that workers can not work. This has an impact on the declining implementation schedule. The decline of work execution schedule can be overcome by accelerating the work or increasing the volume of work (overtime) if the weather is back to normal Conclusion

\section{vIII. Conclusion}

Based on the evaluation results from the beginning of the implementation up to $13^{\text {th }}$ week on the project performance it can be noted that the curve lines formed show that the performance of the project varied ie sometimes the project accelerated or delayed.

The application of the earned value method shows that the project time performance from the first week to the 13th week experienced some deviations, ie at the 4th, 8th and 13th weeks. So the project has decreased time performance at a cost that is less than the budget.

\section{Acknowledgment}

The author wish to express their gratitude and deep appreciation to Stepan Annis, Faculty of Engineering Civil Engineering Department for their assistance and help.

This research was supported by Universitas Kristen Indonesia Paulus Makassar. The author are grateful to the authorities for thei support.

\section{References}

[1] Ervianto, W. I., 2005. Construction Project Management, Andi, Yogyakarta.

[2] $\longleftarrow$ 2005. Theory-Application Project Management Construction, Andi, Yogyakarta.

[3] Soeharto, Faith, 1995. Project Management From Conceptual to Operational, Erlangga, Jakarta.

[4] Thoenggsal, James. (2015). Control of Time and Cost of Project Implementation of Road Improvement of Trans Yamdena Tumbur Regency of South West Maluku by Using Earned Value Management (EVM) Method. Master's Thesis At engineering Faculty UKIP Makassar: unpublished.

[5] Stoner, J.A.F. 1996. "Management Volume II Edition Bahasa Indonesia", Publisher Prenhallindo, Jakarta.

[6] Nurul Gofar, Khairul Annar Kassiml," Introduction to Geotechnical Engineering" Prentice Hall, Pearson Education South Asia Pte, Ltd, Singapore, 2007, Publishers.

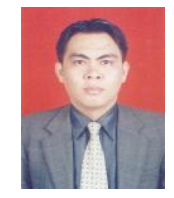

Herby Calvin Pascal Tiyow

Lecture at Universitas Kristen Indonesia Paulus, Makassar. Head of Administration and Human Resources Development at Universitas Kristen Indonesia Paulus, Makassar.

Specialist of Construction Engineering Management

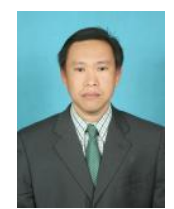

Irwan Lie Keng Wong

Lecture at Universitas Kristen Indonesia Paulus, Makassar. Secretary Postgraduate at Universitas Kristen Indonesia Paulus, Makassar.

Specialist of Geotechnical Engineering 